\title{
Flight activity of rove beetles (Coleoptera: Staphylinidae) in the agricultural landscape in the Leningrad Region
}

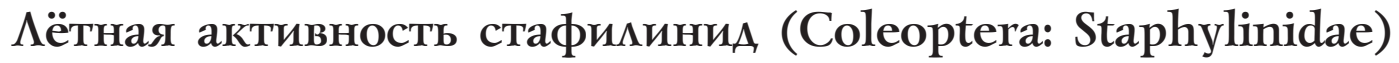 в агроландшафте Аенинградской области}

\author{
O.G. Guseva, A.G. Koval \\ О.Г. Гусева, А.Г. Коваль
}

\begin{abstract}
All-Russian Institute of Plant Protection, Podbelskogo 3, St. Petersburg, Russia. E-mail: olgaguseva-2011@yandex.ru Всероссийский НИИ защиты растений, шоссе Подбельского, 3, Санкт-Петербург, Россия.
\end{abstract}

KEY WORDS: agricultural landscape, biodiversity, species composition, window traps.

КЛЮЧЕВЫЕ СЛОВА: агроландшафт, биоразнообразие, видовой состав, оконные ловушки.

ABSTRACT. This paper presents the study of the flight activity of rove beetles by window traps in the different biotopes of agricultural landscape in the Leningrad Region. We found 50 rove beetles species of 30 genera in the fields and on the field margins as a result of window trapping. Flight intensity was high among Atheta laticollis (Steph.) (18.7\% of the total number of collected specimens), Amischa analis (Grav.) (15.5\%), Philonthus addendus Sharp (10.6\%) and Megarthrus nitidulus Kraatz (9.9\%). The highest species diversity is recorded in the agrocenosis of spring rape and on the field margins. Window traps are a promising method for studying biodiversity and abundance of rove beetles.

РЕЗЮМЕ. Проведено исследование лётной активности стафилинид в различных биотопах агроландшафта Ленинградской области с помощью оконных ловушек. Этим методом на полях и их обочинах было выявлено 50 видов стафилинид из 30 родов. Высокие показатели лётной активности отмечены для Atheta laticollis (Steph.) (18.7\% от общего количества собранных особей), Amischa analis (Grav.) (15.5\%), Philonthus addendus Sharp (10.6\%) и Megarthrus nitidulus Kraatz (9.9\%). Наибольшее видовое разнообразие отмечено в агроценозе ярового рапса и на обочинах полей. Показано, что оконные ловушки являются перспективным методом изучения биоразнообразия и обилия стафилинид.

\section{Introduction}

Rove beetles (Coleoptera: Staphylinidae) are among the most numerous and, at the same time, insufficiently studied beetles in agricultural landscapes. Their ability to fly is crucial for their survival. First, they are able to survive the challenges posed by the landscape changes which originate in human agricultural activity. Second, it enables them to choose the habitats with the most favorable ecological conditions. Finally, it helps them to play an important role as predators of pests of agricultural plants.

Window traps are used to measure the rove beetles' flight activity. Window traps were first used in agricultural landscapes in Germany [Markgraf, Basedow, 2003], which helped reveal more than 80 species of these beetles. The same method was used for studying biotopic distribution of rove beetles of Tachyporinae subfamily in the Moscow Region [Semenov, 2012]. However, this method has never been used in the agricultural landscapes of the Leningrad Region. This paper aims to fill this gap by researching those species of rove beetles which have the highest levels of flight activity on different agricultural fields and their margins in the Leningrad Region.

\section{Materials and methods}

The species composition and the abundance of Staphylinidae were measured using window traps in 2018 and 2019. The work was carried out in the agricultural landscape of the Menkovo Research Station (MRS) of the Agrophysical Research Institute in the village of Menkovo (59 $\left.24^{\prime} 56.6^{\prime \prime} \mathrm{N}, 30^{\circ} 02^{\prime} 03.9^{\prime \prime} \mathrm{E}\right)$ of the Gatchina District in the Leningrad Region.

The window traps are made out of plastic trays with the plexiglass (transparent plastic) plates (size 500x350x4 $\mathrm{mm}$ ) mounted atop. These traps are filled with $500 \mathrm{ml}$ of a $50 \%$ propylene glycol solution. The traps were installed in fields of perennial grasses (clover, timothy grass), rye, spring barley, vetch-oat mixture, spring rape, and in adjacent semi-natural habitats - the field margins (the biotope combines herbaceous vegetation and shrubs).

How to cite this article: Guseva O.G., Koval A.G. 2020. Flight activity of rove beetles (Coleoptera: Staphylinidae) in the agricultural landscape in the Leningrad Region // Russian Entomol. J. Vol.29. No.2. P.153-156. doi: 10.15298/rusentj.29.2.05 
The traps were installed in May and checked every 7 days until the ripening and harvesting of the crop began.

Altogether, 781 individuals of rove beetles were collected and determined. We identified most of the specimens ourselves. The work by Assing and Schülke [2012] was used to determine Staphylinidae. Some specimens were identified by V.I. Gusarov (Natural History Museum, University of Oslo, Norway), and by A.V. Kovalev (All-Russian Institute of Plant Protection, St. Petersburg, Russia).

The species richness was estimated by Margalef index: $D \operatorname{mg}=(S-1) / \ln N$, where $S$ is the number of the species recorded and $N$ is the total number of individuals of all the species [Magurran, 1988].

\section{Results and discussion}

Window trapping in the MRS agricultural landscape revealed 50 species of rove beetles that belong to 30 genera, and to 8 subfamilies. The species richness is distributed in the various fields as follows: spring rape - 30 species, spring barley -25 , rye -19 , vetch-oat mixture - 16, grasses - 11 species (Table).

Table. Rove beetles collected by windows traps in agricultural fields and on the field margins. Таблица. Стафилиниды, собранные оконными ловушками на полях и их обочинах.

\begin{tabular}{|c|c|c|c|c|c|c|c|}
\hline \multirow[b]{2}{*}{ Species } & \multirow[b]{2}{*}{ SF } & \multicolumn{6}{|c|}{ Biotope } \\
\hline & & $\begin{array}{l}\text { spring } \\
\text { barley }\end{array}$ & $\begin{array}{l}\text { vetch-oat } \\
\text { mixture }\end{array}$ & $\begin{array}{l}\text { spring } \\
\text { rape }\end{array}$ & rye & $\begin{array}{l}\text { clover, } \\
\text { timothy } \\
\text { grass }\end{array}$ & $\begin{array}{c}\text { field } \\
\text { margins }\end{array}$ \\
\hline Deliphrum tectum (Paykull, 1789) & Om & & & & & & 12 \\
\hline Anthophagus angusticollis (Mannerheim, 1830) & Om & & & & & & 3 \\
\hline Anthophagus caraboides (Linnaeus, 1758) & Om & & & & & & 2 \\
\hline Megarthrus denticollis (Beck, 1817) & $\operatorname{Pr}$ & & & 2 & & & \\
\hline Megarthrus nitidulus Kraatz, $1857^{*}$ & $\operatorname{Pr}$ & & & 76 & & & 1 \\
\hline Proteinus laevigatus Hochhuth, 1872 & $\operatorname{Pr}$ & 1 & & 6 & & & \\
\hline Carpelimus elongatulus (Erichson, 1839)* & $\mathrm{Ox}$ & & 1 & 1 & & & \\
\hline Carpelimus subtilis (Erichson, 1839)* & $\mathrm{Ox}$ & & & 1 & & & 1 \\
\hline Anotylus nitidulus (Gravenhorst, 1802) & $\mathrm{Ox}$ & 4 & 1 & 6 & 2 & & 1 \\
\hline Anotylus rugosus (Fabricius, 1775) & $\mathrm{Ox}$ & 2 & & 48 & 1 & & 3 \\
\hline Stenus lustrator Erichson, $1839^{*}$ & Sn & & 1 & & & & \\
\hline Rugilus rufipes Germar, 1836 & $\mathrm{Pd}$ & 1 & & & & & \\
\hline Atrecus affinis (Paykull, 1789)* & St & & & 2 & & 1 & 1 \\
\hline Gyrohypnus angustatus Stephens, 1833 & St & & & 1 & 1 & & \\
\hline Xantholinus tricolor (Fabricius, 1787) & St & & & & & & 1 \\
\hline Othius volans J. Sahlberg, 1876 & St & 1 & & & & & \\
\hline Gabrius breviventer (Sperk, 1835) & St & 2 & 1 & 9 & 1 & 1 & 2 \\
\hline Philonthus addendus Sharp, 1867 & $\mathrm{St}$ & 30 & 6 & 38 & & 8 & 1 \\
\hline Philonthus carbonarius (Gravenhorst, 1802) & St & & & 1 & & & \\
\hline Philonthus cognatus Stephens, 1832 & St & 1 & & 1 & 2 & & \\
\hline Philonthus concinnus (Gravenhorst, 1802) & St & 4 & 2 & 5 & 1 & 1 & \\
\hline Philonthus pseudovarians A. Strand, 1941 & St & 2 & 3 & 4 & & & \\
\hline Philonthus laminatus (Creutzer, 1799) & St & & & & 1 & 1 & \\
\hline Philonthus nitidus (Fabricius, 1787)* & $\mathrm{St}$ & 1 & & & & & \\
\hline Philonthus rotundicollis (Ménétriés, 1832) & St & & & & 1 & & \\
\hline Philonthus succicola Thomson, 1860 & $\mathrm{St}$ & 10 & 3 & 3 & 1 & 6 & \\
\hline Ontholestes murinus (Linnaeus, 1758) & St & 1 & & & & & \\
\hline Mycetoporus lepidus (Gravenhorst, 1806) & $\mathrm{Tp}$ & 1 & 1 & 1 & 1 & 1 & 2 \\
\hline Ischnosoma splendidum (Gravenhorst, 1806) & $\mathrm{Tp}$ & & & & & & 1 \\
\hline Lordithon lunulatus (Linnaeus, 1760) & $\mathrm{Tp}$ & & & & & & 2 \\
\hline Lordithon thoracicus (Fabricius, 1777) & $\mathrm{Tp}$ & & & & & 1 & \\
\hline Tachinus proximus Kraatz, 1855 & $\mathrm{Tp}$ & & & & & & 1 \\
\hline Tachinus rufipes (Linnaeus, 1758) & $\mathrm{Tp}$ & & 2 & 9 & & & 4 \\
\hline Tachyporus chrysomelinus (Linnaeus, 1758) & $\mathrm{Tp}$ & 1 & 1 & 6 & 2 & 1 & \\
\hline Tachyporus hypnorum (Fabricius, 1775) & $\mathrm{Tp}$ & & & 2 & 1 & & \\
\hline Tachyporus nitidulus (Fabricius, 1781) & $\mathrm{Tp}$ & & & & 1 & & \\
\hline
\end{tabular}




\begin{tabular}{|c|c|c|c|c|c|c|c|}
\hline \multirow[b]{2}{*}{ Species } & \multirow[b]{2}{*}{ SF } & \multicolumn{6}{|c|}{ Biotope } \\
\hline & & $\begin{array}{l}\text { spring } \\
\text { barley }\end{array}$ & $\begin{array}{c}\text { vetch-oat } \\
\text { mixture }\end{array}$ & $\begin{array}{l}\text { spring } \\
\text { rape }\end{array}$ & rye & $\begin{array}{l}\text { clover, } \\
\text { timothy } \\
\text { grass }\end{array}$ & $\begin{array}{c}\text { field } \\
\text { margins }\end{array}$ \\
\hline Oxypoda sp. & $\mathrm{Al}$ & & & 5 & & & 1 \\
\hline Gyrophaena sp. & $\mathrm{Al}$ & 3 & & 1 & 1 & & 2 \\
\hline Zyras humeralis (Gravenhorst, 1802) & $\mathrm{Al}$ & & & & & & 1 \\
\hline Amischa analis (Gravenhorst, 1802) & Al & 58 & 7 & 24 & 9 & 2 & 21 \\
\hline Aloconota gregaria (Erichson, 1839) & $\mathrm{Al}$ & 7 & & 1 & & & 2 \\
\hline Autalia rivularis (Gravenhorst, 1802)* & Al & 1 & & & & & \\
\hline Atheta laticollis (Stephens, 1832) & $\mathrm{Al}$ & 16 & 26 & 83 & 12 & 2 & 7 \\
\hline Atheta sp. & $\mathrm{Al}$ & 2 & & & & & 4 \\
\hline Mocyta fungi (Gravenhorst, 1806) & $\mathrm{Al}$ & 7 & 2 & 5 & 2 & & 4 \\
\hline Dinaraea angustula (Gyllenhal, 1810) & $\mathrm{Al}$ & 2 & & 2 & & & 3 \\
\hline Aleochara bilineata (Gyllenhal, 1810) & $\mathrm{Al}$ & 2 & & 3 & 3 & & \\
\hline Aleochara bipustulata (Linnaeus, 1761) & $\mathrm{Al}$ & 2 & 2 & 1 & 1 & & \\
\hline Aleochara curtula (Goeze, 1777) & $\mathrm{Al}$ & & 1 & & & & \\
\hline Aleochara fumata Gravenhorst, $1802 *$ & $\mathrm{Al}$ & & & 1 & & & 62 \\
\hline No of species & & 25 & 16 & 30 & 19 & 11 & 26 \\
\hline No of specimens & & 159 & 60 & 349 & 44 & 25 & 145 \\
\hline Dmg & & 4.73 & 3.67 & 4.95 & 4.76 & 3.11 & 5.02 \\
\hline
\end{tabular}

SF — subfamily: Pr — Proteininae, Om — Omaliinae, Ox - Oxytelinae, Sn — Steninae, Pd - Paederinae, St - Staphylininae, Tp Tachyporinae, Al - Aleocharinae; * - species were not collected by pitfall trapping.

$\mathrm{SF}$ - подсемейства: Pr — Proteininae, Om - Omaliinae, Ox — Oxytelinae, Sn — Steninae, Pd — Paederinae, St — Staphylininae, Tр - Tachyporinae, Al — Aleocharinae; * — виды, не собранные в почвенные ловушки.

Among the collected rove beetles, 17 species were collected on herbaceous vegetation using sweep net sampling [Guseva, Shpanev, 2019], and 42 have been found in pitfall traps during our previous investigations in the MRS agricultural landscape [Guseva, 2014, 2017, 2019; Guseva, Koval, 2015, 2017].

Some species (Megarthrus nitidulus, Carpelimus subtilis, Atrecus affinis, Philonthus nitidus) have never been found in the MRS agricultural landscape before. Thus, window traps may help reveal those species, which cannot be observed using any other methods of collection.

Most of the caught species (15) belong to the Staphylininae subfamily (see Table). Most of its representatives are active predators proficient in flying. Philonthus of a large size with a wide head and long mandibles are known to be the most active predators [Tikhomirova, 1973]. In addition, the width of the predator's head is known to be correlated with the size of its prey [ibid.]. Philonthus succicola, and Ph. addendus play the role of these predators in the MRS landscape. At the same time, $P h$. addendus is one of the most numerous species: the share of this species is as large as $10.8 \%$ of the total number of Staphylinidae (Table).

Imago Ph. succicola, along with other representatives of this genera, is known to prey on fly larvae [Hinton, 1954]. It is likely also true for Ph. addendus, because imago of this genus were many times registered in experiments with rotting pig corpses populated with Dryomyzidae, Muscidae, and Piophilidae larvae [Jarmusz et al., 2020].
The window traps caught 14 species of Aleocharinae, and 9 species of Tachyporinae. Predatory behavior is inherent to the representatives of these subfamilies [Tikhomirova, 1973; Assing, Schülke, 2012]. Aleocharinae includes the most numerous species (according to the results of windrow trapping) - Atheta laticollis (18.7\% of a total number of specimens), and Amischa analis (15.5\% respectively). These species were caught in a plant layer of the MRS agricultural landscape by sweeping [Guseva, Shpanev, 2019]. The peculiarities of their feeding and their role in the agricultural biocenoses still need further investigation.

The Oxytelinae subfamily includes 4 species, Proteininae and Omaliinae - 3, Steninae - 1, Paederinae - 1. Oxytelinae is known to have a varied nutrition, while Steninae is specialized to feed on moving prey [Tikhomirova, 1973]. Proteininae and Omaliinae are arguably connected with rotting organic substrates as well [Assing, Schülke, 2012]. Proteininae are also considered to be mycophagous and saprophagous, in other words, they tend to feed on decomposing products [Newton, 1984]. According to the results of windrow trapping, the Proteinnae subfamily includes one of the most numerous species - Megarthrus nitidulus $(9.9 \%$ of all specimens).

As the results of window trapping suggest, the highest number of species (30) is registered in the agrocenosis of spring rape and on the field margins (26), while the biodiversity $(\mathrm{Dmg})$ peaks on the field margins reaching 5.02 (see Table). The lowest number of species and lowest $D \mathrm{mg}$ values are registered in perennial grass 
fields, which is caused by the interruption of investigation due to mowings.

Among the species caught by window trapping in the spring rape agrocenosis, 5 have never been found in pitfall traps. Pitfall trapping had only revealed 25 species of rove beetles throughout many years of research [Guseva, 2017]. Aleochara bilineata, and Dinaraea angustula, prevailed among them, while Philonthus spp. was also numerous, but only in the areas of thick grass. Window trapping, however, shows that completely different species are prevailing in this agrocenosis, namely — Atheta laticollis, Megarthrus nitidulus, and Anotylus rugosus (see Table).

Rove beetles of the genus Philonthus are known to feed readily on the rape blossom beetle (Meligethes aeneus Fabricius, 1775) larvae in the laboratory conditions [Guseva, 2017]. It might be the case that the presence of these pests together with the likely microclimate in the field is one of the factors to attract larger and better-flying predators such as Philonthus adden$d u s$ (see Table).

Our results differ from those of a similar research which was held in central Germany. There, 84 staphylinid species were observed by window traps on the borders between fields of sugar beet and cereals in Germany, where the flight intensity was the highest in Anotylus spp. and Tachyporus hypnorum [Markgraf, Basedow, 2003]. The rove beetles collected by window traps in the NorthWest of Russia are different both in terms of their species composition and their abundance. Of the 50 rove beetles species which were observed by window traps in the conditions of the Leningrad Region, Atheta laticollis, Amischa analis, Philonthus addendus, and Megarthrus nitidulus demonstrated the highest flight activity. Of them, M. nitidulus has never been registered throughout the many years of research conducted using different methods. As a result, we claim that window trapping is a method which is fruitful for studying biodiversity and the abundance of Staphylinidae.

Acknowledgments. We are sincerely grateful to V.I. Gusarov (Natural History Museum, University of Oslo, Norway) and A.V. Kovalev (All-Russian Institute of Plant Protection, St. Petersburg, Russia) for their help with material identification. The study was performed within the frames of the Russian State Research Project no. 0665-2018-0008.

\section{References}

Assing V., Schülke M. 2012. Die Käfer Mitteleuropas. Band 4. Staphylinidae (exklusive Aleocharinae, Pselaphinae und Scydmaeninae). Zweite neubearbeitete Auflage. Heidelberg: Spektrum Akademischer Verl. S.I-XII, 1-560.

Guseva O.G. 2014. [The rove beetle Aloconota gregaria Er. (Coleoptera, Staphylinidae) as a polyphagous predator in the agricultural landscapes of Northwestern Russia] // Plant Protection News. Vol.1. P.17-20 [in Russian, with English summary].

Guseva O.G. 2017. [Ground-dwelling predatory arthropods in the agrocenosis of spring rape in Northwestern Russia] // Zashchita i karantin rasteniy. No.8. P.45-47 [in Russian, with English summary].

Guseva O.G. 2019. [Investigation of biodiversity and distribution of rove beetles (Coleoptera, Staphylinidae) in the agricultultural landscapein Northwestern Russia] // Acta Biologica Sibirica. Vol.5. No.1. P.12-18 [in Russian, with English summary].

Guseva O.G., Koval A.G. 2015. Influence of soddy-podzolic soil improvement on the abundance and structure of complexes of epigeic predatory beetles (Coleoptera: Carabidae, Staphylinidae) in Northwestern Russia // Entomological Review. Vol.95. No.8. P.1051-1060.

Guseva O.G., Koval A.G. 2017. [Aleocharines (Staphylinidae, Aleocharinae) in agricultural landscapes with different soil in Northwestern Russia] // Informatsionny byulleten VPRS MOBB. No.52. P.99-103 [in Russian].

Guseva O.G., Shpanev A.M. 2019. Rove beetles (Coleoptera, Staphylinidae) on agricultultural landscapeherbaceous vegetation in the Leningrad Region // Russian Entomological Journal. Vol.28. No.4. P.373-376.

Hinton H.E. 1954. A monograph of the beetles associated with stored products. London: British Museum Natural History. 443 pp.

Jarmusz M., Grzywacz A., Bajerlein D. 2020. A comparative study of the entomofauna (Coleoptera, Diptera) associated with hanging and ground pig carcasses in a forest habitat of Poland // Forensic Science International. Vol.309. Art.110212. P.1-13.

Magurran A.E. 1988. Ecological diversity and its measurement. Princeton: Princeton University Press. 192 pp.

Markgraf A., Basedow T. 2003. Flight activity of predatory Staphylinidae in agriculture in central Germany // Journal of Applied Entomology. Vol.126. Iss.2/3. P.79-81.

Newton A.F. 1984. Mycophagy in Staphylinoidea (Coleoptera) // Q.D. Wheeler, M. Blackwell (eds.). Fungus-insect relationships: perspectives in ecology and evolution. New York: Columbia University Press. P.302-353.

Semenov V.B. 2012. [Staphylinid beetles of the subfamily Tachyporinae (Coleoptera: Staphylinidae) of the Moscow Region] // Eversmannia. Nos 29-30. P.30-39 [in Russian].

Tikhomirova A.L. 1973. [Morphological features and phylogeny of the rove beetles (with catalog of the fauna of the USSR)]. Moscow: Nauka Publ. 192 pp. [In Russian] 